International Journal of Engineering \& Technology, $7(4.34)(2018) 208-213$
International Journal of Engineering \& Technology
SPC
Website: www.sciencepubco.com/index.php/IJET
Research paper

\title{
The Impact of Audit Committee and Internal Audit towards Financial Statement Quality: External Audit and Corporate Governance as Intervening Variables
}

\author{
Islahuzzaman*, Syafdinal, Syakieb Arsalan, Maya Lisa Aryanti \\ Widyatama University, Bandung, Indonesia \\ *Corresponding author E-mail: islahuzzaman@widyatama.ac.id
}

\begin{abstract}
A financial statement is a crucial matter since its quality is declining. This research developed and tested a theoretical model which identified factors directly or indirectly contributing to the financial statement quality, namely audit committee and internal audit; meanwhile, external audit and corporate governance were considered as antecedent factors having impact on the report. The objective of the research is to gain insight on such factors. The objective of the research is to gain insights on factors that affect such reports. The findings showed consistent evidence supporting the theoretical model. They also showed how AC and IA simultaneously and partially impacted the quality of financial statements (QFS). AC and IA directly or indirectly affect the quality of the financial statement. They also have indirect effects through CG and EA in enhancing the quality to $77 \%$.
\end{abstract}

Keywords: Audit Committee; Internal Audit; Financial Statement Quality; External Audit; Corporate Governance.

\section{Introduction}

A company is subject to present a financial statement with quality as its responsibility to authorities. The Financial Accounting Standards [28] establishes qualitative characteristics to be obtained in accounting information commonly used in decisionmaking processes.

According to the International Financial Reporting Standard (IFRS) [30], the quality of information guarantees innately accurate and transparent conveyance. Therefore, the company is encouraged to submit a financial statement which is honest and error-free. In reality, however, some companies manipulate their reports in various business practices. Some of the manipulation scandals implied large companies which used to have high audit quality in the United States of America namely Enron, Tyco, Global Crossing, and Worldcom [27]. The same cases also occurred in Indonesia, such as PT. Lippo Tbk and PT. Kimia Farma Tbk, also involving financial reporting with an initial indication of manipulation [24].

The cases exhibited involvements of internal parties of the companies such as CEO, commissioners, audit committees, and internal auditors in committing accounting fraudulence. The cases also advocated the assumption that good corporate governance has not been implemented well. To improve the quality of financial statement, it must be implemented by internal and external parties of the company [57, 62].

The accountant as a profession plays a vital role in guaranteeing reliable financial information for the government, investors, creditors, stakeholders, staff, debtors, the society, and other parties of interest. Regrettably, public accountants as external auditors who provide an evaluation of the fairness of the report are increasingly losing their credibility and independence. The condition is evident as there is an increase in lawsuits against public accountants [27].
Therefore, the author concluded that there is a need for further investigation on how Internal Audit (IA) interacts with Audit Committee (AC) in the corporate governance (CG) and how such interaction simultaneously affect the quality of the financial statement (QFS). To date, there is almost no study which directly investigates how Internal Audit (IA) and Audit Committee (AC) affects the corporate governance (CG) and external audit (EA). Previous researches regarding commissioner boards and Audit Committee $(\mathrm{AC})$ were in line with the findings $[1,7-8]$. This research points to the way Audit Committee (AC) and Internal (IA) affect the quality of financial statements, directly or indirectly through corporate governance (CG) and the role of External Audit (EA).

\section{Theoretical Development}

\subsection{The Quality of Financial Statements}

The International Accounting Standard Board [29] stipulated two fundamental qualities in the information namely relevance and faithful representation, included in the financial statement to be useful in making decisions in the economy. Apart from that, other qualities that can enhance the usefulness of financial statements include comparability, verifiability, timeliness, and understandability [22]. Faithful representation refers to conveying information in transparency and honesty by describing the real condition of the economy, presented in a complete, neutral, and error-free manner. Completeness refers to providing complete, decision-making information to avoid misleading the user. Information upholds neutrality when it is free from being biased towards the interest of a particular party. A financial statement should also be free from error which can mislead users and obstruct the quality of faithful representation [33]. 


\subsection{The Relationship of Audit Committee (AC) and Quality of Financial Statement}

An audit committee is a committee of directors of an organization with special responsibilities to review annual reports, observe financial statements, and reveal findings before submitted to the board of directors.

The committee assists the commissioner board to monitor the processes of financial statement reporting by the management to enhance the credibility of the financial report $[3,13]$. AC functions as evaluators and advocates for the stipulated accounting policies, and they are dependable in influencing the approach of the company towards financial reporting, the level of transparency, and the compliance towards standards of practices. An analysis provided proof of positive relationships between the presence of $\mathrm{AC}$ and the quality of the financial statement: deviation and adjustments in revenue found in reports were corrected in the next period, and the potential for manipulation was minimal [21]. Meanwhile, cases of report manipulation were dominated by companies without AC [20]. Other proofs documented AC closely connected to the reduction of errors and manipulation of reports as some indicators of the quality of the financial reporting [49].

\subsection{The Relationship of Corporate Governance (CG) and Financial Reporting (QFS)}

There are debates regarding strong corporate governance [48] Good governance by the board of directors has been proven to influence the quality of financial statement, which in turn fundamentally affect the level of trust from investors.

One of the functions applicable in corporate governance is assuring the quality of the process of finance statement. Additionally, academic research has found the relationship between weakness in governance and the low quality of the financial statement, manipulation of revenue, finance report fraudulent, and inadequate internal monitoring [7-9, 16, 20, 34-37, 49]. With the development above, there are emphases on the need to improve corporate governance on financial statement [40-45] such as initiating reformation in the auditing committee [11, 55-56].

The process of the governance affects the quality of financial statement (for example transparency, objectivity). Even though the expectation is that a 'better' corporate governance orients to better financial reporting, there is no consensus regarding the definition of 'the quality of financial reporting'.

\subsection{The Relationship of External Audit (EA) and the Quality of Financial Statement}

An independent auditor is a public accountant who provides auditing services in checking for errors in financial statement. An external auditor is a professional auditor who provides services for the public, especially in auditing financial statement their clients made [51].

Auditing activities contribute to the quality of the financial statement. To ensure the quality and the usefulness in making decisions in the economy, a company should enforce relevance, faithful representation, comparability, verifiability, timeliness, and understandability. Therefore, financial statement must be audited by an independent and competent external auditor (EA). Independent auditors are usually CPA's who are either individual practitioners or members of public accounting firms who render professional auditing services to clients" [12]. By considering the traits of independence and competency in public accountants, the users such as investors and creditors can rely on the reports in making decisions because they can trust the integrity of the report released by the public accountant [4].

\subsection{The Relationship between Internal Auditor (IA) and Financial Statement}

An internal auditor acts as a mediator to improve and make an organization more efficient based on insights and recommendations from analysis deriving from the data and the internal process of the company. An internal auditor is recognized as a staff assigned to monitor and audit so that the system and the documentation of the financial report of the company can be optimized. Since the internal auditor knows the aspects of the company, they can effectively detect fraudulence in the report [61]. Internal auditors play an important role in preventing deceit and significantly reduce costs related to similar activities [18].

Previous studies employed analytical tests to investigate the way internal audit discover discrepancies in financial statement [18]. In [18] described how internal auditors were sensitive towards affecting factors in financial report discrepancies. In [32, 47, 59] stated that information gained from internal audit influenced the perception of the stakeholders towards the reliability of the report.

\subsection{The Relationship of Audit Committee (AC) and Corporate Governance (CG)}

Besides internal and external audits, an auditing committee holds the key to enhance the quality of the corporate governance in banks $[10,38]$. The committee focuses on corporate governance, especially in internal corporate controlling and financial accounting system. Corporate governance is defined as "a system which guides and control the company" [14]. Therefore, it can be assumed that the concept of such governance is related to various activities, regulations, guidelines, processes, and procedures. They ensure the resources of the company is optimally managed and employed by the board of directors and in turn orient to achieving the goals to which the company has committed and protect the interests of the stakeholders and the society in general [2].

According to the Organization for Economic Cooperation and Development (OECD) [65], corporate governance is a set of regulations for managers, directors, commissioners, shareholders and other stakeholders. In the corporate governance mechanism, there are proxies namely independent commissioners, managerial ownership, institutional ownership, and auditing committee.

The governance may include aiding the management in setting the strategic direction as well as management control activities [64]. Even though the subject of corporate governance in developing countries lately have gained attention in literature $[46,52]$ such governance is almost in a neglected state [15]. To be specific, most of the studies dedicated themselves to observe the role of the auditing committee in corporate governance focus on the role of the committee in duties and responsibilities $[8,50,53]$.

\subsection{The Relationship of Audit Committee (AC) and Ex- ternal Auditor (EA)}

The audit committee holds an essential role in supervising the quality of the audit and the financial statement. Most of the committees choose to consider the whole auditing process and their experiences with an auditor based on the quality of their audits.

The committee has significant responsibilities in preparing the audit and ratify the internal control system, and resolve differences in the accounting principles of the company $[23,31]$ and the interests of external audits.

A company appoints the committee as a mediator between the board of directors and the external audits, internal auditors with independent members whose job is to provide supervision. The interaction among the audit committee, external auditors, internal auditors, the board, and the management is crucial in being a competent governing body to produce a high quality of financial statement. The external auditor needs to prepare themselves for communication with the audit committee regarding the quality (and not the acceptability) of the report [55]. 


\subsection{The Relationship of Audit Committee (AC) and Corporate Governance (CG)}

Internal auditing activities have been widened to allow their functions to apply to the mechanism of key corporate governance $[19,25]$. Sarbanes-Oxley laws [55] and SEC regulations [56] emphasized the importance of the internal audit function as an asset to the governance. Internal auditors have the opportunities to provide their organization with the highest value from improving the corporate governance. The definition of an internal auditor shows that the range of responsibilities of a professional auditor includes the evaluation and the improvement of corporate governance [58]. Since it is the responsibility of the internal auditor to assist the organization to achieve its goals through a systematic and disciplined approach to evaluate and improve the processes in risk management, they have the critical role in the process of the governance [17]. The Indonesian Internal Auditor Organization [54] also mentioned the relationship between the internal audit and good corporate governance, which is: "The Organization believes that the effective function of internal audit is capable of offering important contributions in enhancing the processes in corporate governance, risk management, and management control. Internal auditors are a vital support for commissioners, audit committees, directors, and senior management in forming the foundation for the development of corporate governance."

\subsection{The Relationship of Internal Audit (IA) and Exter- nal Audit (EA)}

The majority of external auditors depend on internal auditors within a limited span of time and such dependency needs to increase in the future [63]. To make decisions regarding the level of dependency on the works of internal auditors, external auditors need to assess the quality of the internal audit. Most of the work of internal auditors may be useful for external auditors in determining the nature, the duration, and the span of work of the audit. However, such dependency may be less should the 'in-house' internal audit be compared to 'outsourced' internal audit because it is regarded as less independent [26].

2.10. The Relationship of Audit Committee (AC) with Financial Statement through Corporate Governance (CG) and External Audit (EA)

External auditors play an important role in monitoring and assisting the improvement of financial statement and therefore can be considered as an essential party in corporate governance. Auditors must be ready to discuss with the audit committee regarding the quality and not only the acceptability of the report [55]. In [39] pioneered the notion that committee independency manifestation will increase the independence of an auditor and raise transparency in the report.

Among other responsibilities, the audit committee monitors policy and procedure compliance and evaluate internal and external audits as well as inspection reports. In this case, in [50] described the role of the audit committee as a monitoring body authorized to carefully observe the process of financial reporting and ensure that the audit of the report is reliable and relevant with the corporate governance.

\subsection{The Relationship of Internal Audit (IA) and Fi- nancial Statement through Corporate Governance (CG) and External Audit (EA)}

Figure 1 depicts the hypothesis structural model for each factor of the study. Every link in the model is labeled with their corresponding hypothesis (with the recommended direction). The model is used to determine the relationship among the audit committee, internal audit, corporate governance, and external audit with financial statement report.

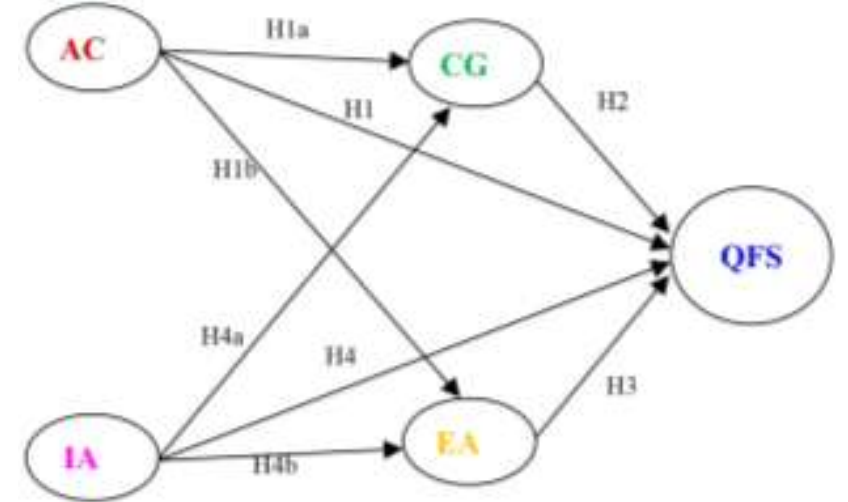

Fig. 1: Theoretical model

\subsection{Direct Association with the Quality of Financial Statement Report}

For the relationship, the following hypotheses were put to the test: H1: The relationship of the audit committee with the quality of the financial statement (QFS).

H2: The Relationship of Corporate Governance (CG) and Financial Statement (QFS)

H3: The Relationship of External Audit (EA) and the Quality of Financial Statement (QFS)

H4: The Relationship of Internal Audit (IA) and the Quality of Financial Statement (QFS)

\subsection{Indirect Association with the Quality of Financial Statement (QFS)}

By combining the relationship between audit committee (AC), internal audit (IA), external audit (EA), and corporate governance (CG), they can provide a deeper understanding about high-quality financial statement. The audit committee and internal audit will encourage the implementation $\mathrm{f}$ corporate governance principles, besides audits from external auditors. In so doing, the financial report published is of high quality. Therefore, the following hypotheses are tested:

H1a: There is a positive relationship of Audit Committee (AC) and Corporate Governance (CG)

H1b: There is a negative relationship between the audit committee (AC) and external auditor (EA)

H4a: There is a positive relationship between internal audit (IA) and Corporate Governance (CG).

$\mathrm{H} 4 \mathrm{~b}$ : There is a negative relationship between internal audit (IA) and external audit (EA)

There is an indirect effect of corporate governance (CG) and external audit (EA) to the relationship between the audit committee (AC) and internal audit (IA) with the quality of the financial statement, with the following theses examined:

H1c: The audit committee (AC) has an indirect effect on the quality of the financial statement (QFS) through the corporate governance (CG) and external audit (EA).

H4c: The internal audit (IA) has an indirect effect on the quality of the financial statement (QFS) through the corporate governance (CG) and external audit (EA).

\section{Methodology}

The data was compiled using a survey spread to audit managers registered in Indonesia. The questionnaire was spread to 619 respondents with 230 of them completed the survey, reaching the effective percentage amounting to $36 \%$. The variables measured in the questionnaire include audit committee, corporate governance, internal audit, and external audit towards the quality of the financial report. The audit committee was measured through direct questions regarding the audit committee. Corporate governance was measured using an instrument adaptive towards the imple- 
mentations of the principles of corporate governance. Internal audit refers to the effectiveness in detecting the possibilities of discrepancies. Subjects answered directly to questions about the internal audit in detecting the discrepancies. The external audit was measured with the audit standard application. The subjects were asked to show the frequency of the audits and the implementations of the corporate governance principles.

\section{Results and Discussion}

Table 1 shows the results of the path analysis and each hypothesis with its corresponding path coefficients. A figurative representation can also be seen in Figure 2. The $\mathrm{R}^{2}$ reported for the dependent variables of financial report quality is $0.55,0.30$ for $C G$ and 0.33 for EA.

Table 1: Path analysis results

\begin{tabular}{|c|c|c|c|c|c|}
\hline $\begin{array}{c}\text { De- } \\
\text { pendent } \\
\text { Varia- } \\
\text { ble }\end{array}$ & $\begin{array}{c}\text { Inde- } \\
\text { pendent } \\
\text { Variable }\end{array}$ & $\begin{array}{c}\text { Associ- } \\
\text { ated } \\
\text { Hypoth- } \\
\text { esis }\end{array}$ & $\begin{array}{c}\text { Path } \\
\text { Coeffi- } \\
\text { cient }\end{array}$ & $\begin{array}{c}\text { T-Statistics } \\
\text { (Bootstrap- } \\
\text { ping) }\end{array}$ & $\begin{array}{c}\text { Signifi- } \\
\text { cant } \\
\text { p-Value }\end{array}$ \\
\hline QFS & AC & H1 & 0.053 & 0.864 & ns \\
\hline QFS & CG & H2 & -0.159 & 1.155 & $\mathrm{p}<0.10$ \\
\hline QFS & EA & H3 & 0.707 & 3.900 & $\mathrm{p}<0.01$ \\
\hline QFS & IA & H4 & -0.192 & 2.690 & $\mathrm{p}<0.01$ \\
\hline CG & AC & H1a: & 0.139 & 1.734 & $\mathrm{p}<0.10$ \\
\hline EA & AC & H1b: & -0.202 & 3.228 & $\mathrm{p}<0.01$ \\
\hline CG & IA & H4a & 0.523 & 7.643 & $\mathrm{p}<0.01$ \\
\hline EA & IA & H4b & -0.518 & 6.750 & $\mathrm{p}<0.01$ \\
\hline
\end{tabular}

Note: ${ }^{*} \mathrm{p}<0.10,{ }^{* *} \mathrm{p}<0.05,{ }^{* * *} \mathrm{p}<0.01, \mathrm{~ns}$ - not significant.

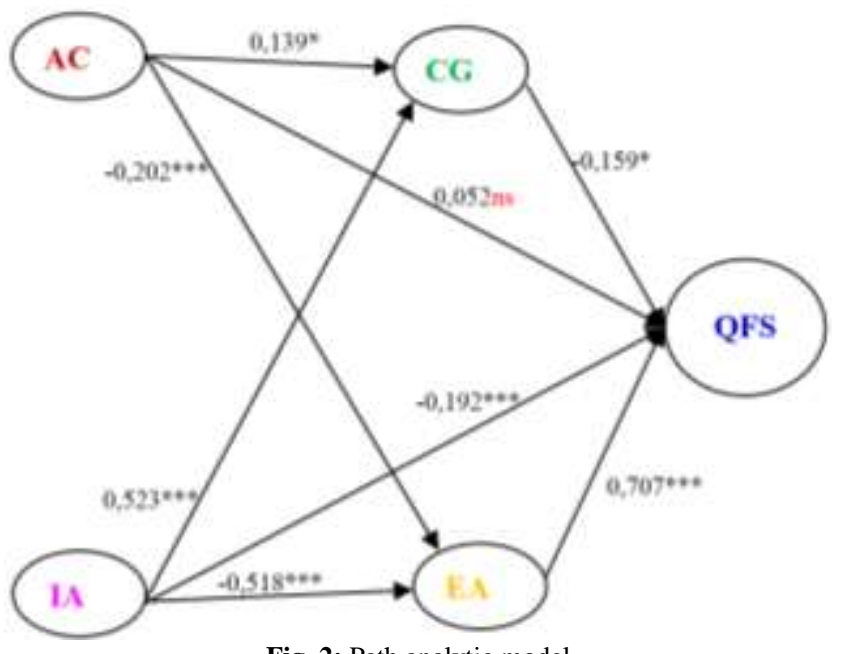

Fig. 2: Path analytic model

The structural model was evaluated based on the $\mathrm{R}^{2}$ and beta coefficients. The stability and significance of the structural path estimation statistics were evaluated using the bootstrap repeated sampling method [60]. Exogenous variables in the model explain some variances: The quality of financial statement have $\mathrm{R}^{2}$ as high as 0.55 ; the $\mathrm{R}^{2}$ of corporate governance $(\mathrm{CG})$ was 0.30 ; the $\mathrm{R}^{2}$ value for external audit (EA) was 0.33. CG and EA collectively contributed $77 \%$ or $\mathrm{R}^{2}=0.434$ from the total variance explained in the composite latent variable. To be more specific, the predictors were significant towards the quality of the financial statement for the corporate governance factor with beta $-0.159, \mathrm{p}<0.10, \%$ $\mathrm{R}^{2}=0.139$; the external audit factor with beta $0.707, \mathrm{p}<$ $0.001, \% \mathrm{R}^{2}=0.635$; and internal audit factor with beta $-0.192, \mathrm{p}<$ $0.001, \% \mathrm{R}^{2}=0.172$. Thus, hypotheses 2,3 , and 4 are acceptable. Hypothesis H1a predicted a positive relationship between the audit committee and corporate governance, while $\mathrm{H} 1 \mathrm{~b}$ predicted a negative relationship between the audit committee and the external audit. Both hypotheses are strongly supported. H1a and H1b are therefore acceptable. For H1a, the beta coefficient is positively significant, amounting to 0.139 ( $\mathrm{p}<0.10)$, and H1b's beta co- efficient negatively sufficient amounting to -0.202 ( $\mathrm{p}<0.01$ ). They translated to the external audit being independent in its audit. The following is the second set of sub-hypothesis of $\mathrm{H} 4 \mathrm{a}$ and $\mathrm{H} 4 \mathrm{~b}$. Hypothesis H4a predicted a positive relationship between internal audit and corporate governance, while $\mathrm{H} 4 \mathrm{~b}$ predicted a negative relationship between internal audit and external audit. Both $\mathrm{H} 4 \mathrm{a}$ an $\mathrm{H} 4 \mathrm{~b}$ is acceptable since the beta coefficient of H4a was 0.523 and it explained the relationship between internal audit and corporate governance by showing that there was a positive effect from internal audit on corporate governance. The beta coefficient of H4b was -0.518 which entailed a negative effect of internal audit on external audit. It was due to the information obtained from the audit committee and the internal audit was considered as input or recommendations for the external audit.

Hypothesis 1c: The audit committee (AC) has an indirect effect on the quality of the financial statement through the corporate governance (CG) and external audit (EA).

The effect was then measured with the intervention variables from corporate governance and external audit which was in line with hypothesis 1c (H1c). The primary relationship evaluated involved indirect effect and intervention. Indirect effects of audit committee towards the quality of financial statement comprised of the following paths and were measured based on the coefficient values of the paths in Table 2.

Path (1) AC - CG - FRQ: $0.139 \times 0.159=0.0221$;

Path (2) AC - EA - FRQ: $-0.202 \times 0.707=-0.1428$; the total of indirect effects: -0.1207 .

Path (1) exhibited indirect effects of audit committee exclusively through corporate governance $(0.0221)$.

Path (2) exhibited indirect effects of audit committee through external audit $(-0.1428)$.

Table 2: Decomposition of observed correlations AC-RFQ

\begin{tabular}{|c|c|c|c|}
\hline Relations & Observed Correlation & Direct Effect & Indirect Effect \\
\hline AC-QFS & $-0.270^{* * *}$ & 0.052 & -0.1207 \\
\hline AC - CG & $-0.263^{* * *}$ & $0.139^{* *}$ & \\
\hline AC - EA & $-0.304^{* * *}$ & $-0.202^{* * *}$ & \\
\hline CG- QFS & $0.135^{* *}$ & $0.154^{*}$ & \\
\hline EA- QFS & $0.215^{* * *}$ & $0.707^{* * *}$ & \\
\hline \multicolumn{3}{|c|}{ Note: ${ }^{*} \mathrm{p}<0.10,{ }^{* *} \mathrm{p}<0.05, * * * p<0.01}$.
\end{tabular}

The results showed that there was a direct relationship between the audit committee and the quality of the financial statement as much as -0.270 and it was based on two effects. First, there was a direct effect of 0.052 (see Table 2). Second, there was an indirect effect amounting to -0.1207 (see Table 2), which can be decomposed further into parts that could be related to external audit amounting to -0.1428 . According to [6], the indirect effect higher than 0.05 could be considered significant and essential in the path analysis. It, therefore, showed the relationships among audit committee, corporate governance, and external audit with financial statement report.

To make sure whether the mediation was simultaneous or partial, the research employed criteria [5] suggested. Indirect effects via corporate governance and the external audit were higher than 0.05 , rendering $\mathrm{H} 1 \mathrm{c}$ was acceptable. For this hypothesis, the relationship between the audit committee and the financial report quality on the zero-order correlation was significant $(\mathrm{r}=-0.270, \mathrm{p}<0.01)$. However, after controlling the indirect effects via considerations in the implementations of corporate governance principles and external audit, the path coefficient was not significant. It meant, therefore, that corporate governance and external audit fully mediated the relationship between the audit committee and the quality of the financial report. Based on the result above, $\mathrm{H} 1 \mathrm{c}$ was acceptable. Additionally, corporate governance and external audit had significant direct effects on the quality of the financial report, in line with their hypotheses 2 and 3. 
This research combined the intervention effect from corporate governance and external audit on the relationship of the audit committee and the quality of the financial report. The results supported $\mathrm{H} 1 \mathrm{c}$, and therefore they provided extra proof to explain the complex relationship. It meant, therefore, that corporate governance and external audit fully mediated the relationship between the audit committee and the quality of the financial report. It also entailed that audit committee indirectly affected the quality of the financial report through the intervention of the implementation of corporate governance principles and external audit.

Hypothesis 4c: The internal audit (IA) has an indirect effect on the quality of the financial statement through the corporate governance (CG) and external audit (EA).

The indirect effect or the effect of internal audit towards the quality of financial report was measured with intervention variables of corporate governance and external audit which was in line with hypothesis $4 \mathrm{c}(\mathrm{H} 4 \mathrm{c})$. Indirect effects of internal audit towards the quality of financial statement comprised of the following paths and were measured based on the coefficient values of the paths in Table 3.

Path (1) IA-CG- QFS: $0,523 \times 0.159=0,0832$;

Path (2) IA-EA- QFS: $-0.518 \times 0.707=-0.3662$; the total of indirect effects: -0.283 .

Path (1) showed that indirect effects through corporate governance were 0.0832 of value, while path (2) showed indirect effects from external audit amounting to -0.3662 . Both paths revealed indirect effects of -0.283 , which was larger than 0.05 . It translated into the condition that the relationship among internal audit, external audit, and corporate governance with financial statement quality comprised of two effects, namely direct and indirect effects.

Table 3: Decomposition of observed correlations IA-QFS

\begin{tabular}{|c|c|c|c|}
\hline Relations & Observed Correlation & Direct Effect & Indirect Effect \\
\hline IA- QFS & $0.125^{* *}$ & $-0.192^{* * *}$ & -0.283 \\
\hline IA - CG & $0.465^{* * *}$ & $0.523^{* * *}$ & \\
\hline IA - EA & $0.578^{* * *}$ & $-0.518^{* * *}$ & \\
\hline CG- QFS & $0.135^{* *}$ & $0.159^{* *}$ & \\
\hline EA- QFS & $0.215^{* * *}$ & $0.707^{* * *}$ & \\
\hline \multicolumn{4}{|c|}{ Note: ${ }^{* *}<0.10,{ }^{* *} \mathrm{p}<0.05, * * * \mathrm{p}<0.01}$.
\end{tabular}

Table 3 displayed correlation decomposition towards direct and indirect effects. Since the indirect effect of corporate governance on the quality of financial statement report was higher than 0.05 , $\mathrm{H} 4 \mathrm{c}$ was deemed acceptable. However, it should be noted that only partial mediation occurred since the correlation between internal audit and the quality of financial statement report was 0.125 and $\mathrm{p}<0.01$ and remained significant $(-0.192, \mathrm{p}<0.01)$ after controlling the effect on mediation at -0.283 .

\section{Conclusion}

The audit committee and internal audit have simultaneous and partial effects on the quality of financial statement. The audit committee and internal audit have direct and indirect effects on the quality of financial statement. The audit committee and internal audit have indirect effects on corporate governance and external audit in improving financial statement. However, the quality of the financial statement is not only affected by factors of the audit committee, internal audit, external audit, and corporate governance alone since there are other intertwining factors involved. It was evident that a 'corporate responsibility' has a significant burden to improve the quality of financial statement, the roles audit committee/internal audit, external audit, and corporate governance have gained momentum in importance. The audit committee has the primary responsibility to ensure the mechanism of company accountability has run and function well to produce high-quality financial statement.
There is strong and coordinated cooperation between audit committee, internal audit, and external audit, besides being supported by effective corporate governance. First, the audit committee has positive effects on the quality of financial statement. It means that the more effective the audit committee, the higher the quality of the financial statement. Second, the external audit has a positive effect on the quality of financial statement. It entails that the more effective the external audit, the higher the quality of the financial statement. Third, there is a negative relationship between the audit committee and the external audit. Thus, the audit committee has a positive effect on the external audit. Fourth, there is a negative relationship between internal audit and external audit. Thus, an internal audit affects external audit.

\subsection{Recommendations}

The Profit and the investment of a company's assets need to be increased so that its going concern is not affected and cause doubts on the part of the auditor on the matter.

Before investing, prospective investors should consider opinions from auditors.

Bank management needs to pay attention to its going concern to avoid the going concern of the audit's viewpoint provided by an independent auditor.

Future research needs to increase the number of samples involved. Future research should also add other variables that build the opinion of an audit's going concern such as the opinion from previous audits and the performance of other financial aspects.

This research contributes to improving the quality of the financial statement report by focusing on the effects of independent variables collectively. The findings provide consistent proofs that it is not only affected by the audit committee, internal audit, external audit, and corporate governance, but also other factors. The implication is that there is a need to understand that the findings have their limitations. First, it should study a survey of a predetermined number of samples. Second, there may be problems of uncontrolled intervention and moderation variables. Third, this research focused only on the realms of auditing and the quality of the financial statement. Further investigation is needed to determine whether the variables in this study also affect the quality of the financial statement in other accounting settings.

\subsection{Limitations}

This research fundamentally has limitations namely the use of three variables ( 2 profitability variables proxied with ROE and ROA) and asset growth (TAG), as well as acceptance towards the opinion of going concern audit. There are, of course, voluminous variables to be studied.

\subsection{Implications}

Inform (prospective) investors about the financial and nonfinancial condition as a tool to predict the longevity of a bank. With the revelation of the bank's going concern stated in the opinion of an audit, the management of the bank can put efforts into maintaining the going concerns as well as improving their work performance.

Investors/creditors can decide on granting a loan and stipulating policies to monitor the granted credits.

\section{References}

[1] Abbott, L. J., Park, Y., \& Parker, S. 2000. The effects of audit Committee activity and independence on corporate fraud. Managerial Finance, 26(11), 55-67.

[2] Abdulsaleh, A. 2014. Corporate governance role of audit committees in the banking sector: Evidence from Libya. International Journal of Social Management, Economics and Business Engineering, 8(2), 592-597.

[3] Bahaudin, A., \& Wijayanti, P. 2011. Mekanisme corporate governance terhadap konservatisme akuntansi di Indonesia. Dinamika Sosial Ekonomi, 7(1), 86-101. 
[4] Arrens, A. A., Randal, J. E., \& Mark, S. B. 2012. Auditing and assurance service: An integrated approach. Prentice Hall.

[5] Baron, R. M., \& Kenny, D. A. 1986. The moderator-mediator variable: Conceptual, strategic and statistical consideration. Journal of Personality and Social Psychology, 26(10), 110-132.

[6] Bartol, K. M. 1983. Turnover among DP personnel: A causal analysis. Communications of the ACM, 26, 807-811.

[7] Beasley, M. S. 1996. An empirical analysis of the relation between the board of director composition and financial statement fraud. The Accounting Review, 71, 443-465.

[8] Beasley, M. S., Carcello, J. V., \& Hermanson, D. R. 2000. Should you offer a job to your external auditor. Journal of Corporate Accounting and Finance, 11(4), 35-42.

[9] Beasley, M., Carcello J., \& Hermanson, D. 1999. Fraudulent financial reporting 1987-1997: An analysis of U.S. public companies. Association of International Certified Professional Accountants

[10] Bishop, W. G., Hermanson, D. R., Lapides, P. D., \& Larry, E. 2000. The year of the audit committee. The Internal Auditor, 57(2), 46-51.

[11] Blue Ribbon Committee. 1999. Report and recommendations of the Blue Ribbon Committee on improving the effectiveness of corporate audit committees. The Business Lawyer, 1067-1095.

[12] Boynton, C. W., \& Raymon, N. J. 2006. Modern auditing. John Wiley and Sons.

[13] Bradbury, M., Mak, Y. T., \& Tan, S. M. 2006. Board characteristics, audit committee characteristics and abnormal accruals. Pacific Accounting Review, 18(2), 47-68.

[14] Cadbury Committee. 1992. Report of the committee on the financial aspects of corporate governance. Professional Publishing Ltd.

[15] Capiro Jr, G., \& Levine, R. 2002. Corporate governance of banks: Concepts and international observations. Proceedings of the The Brookings Institution. World Bank, IMF and Brookings Institution Conference, Building the Pillars of Financial Sector Governance: The Roles of Public and Private Sectors.

[16] Carcello, J., \& Neal, T. L. 2000. Audit committee composition and auditor reporting. The Accounting Review, 75(4), 453-468.

[17] Cattrysse, J. 2005. Reflections on corporate governance and the role of the internal auditor. Roularta Media Group.

[18] Church, B. K., McMillan, J. J., \& Schneider, A. 2001. Factors affecting internal auditors' consideration of fraudulent financial reporting during analytical procedures. Auditing: A Journal of Practice and Theory, 20(1), 65-80.

[19] Cohen, J., Ganesh, K., \& Arnie, W. 2004. The corporate governance mosaic and financial reporting quality. Journal of Accounting Literature, $23,87-152$

[20] Turley, S., \& Zaman, M. 2004. The corporate governance effects of audit committees. Journal of Management and Governance, 8(3), 305332.

[21] DeFond, M. L., \& Jiambalvo, J. 1991. Incidence and circumstances of accounting errors. The Accounting Review, 66, 643-655.

[22] Financial Accounting Standard Board (FASB). 1997. Statement of financial accounting concepts no. 2: Qualitative characteristics of accounting information. FASB.

[23] Akram, H., Basuki, P., \& Budiarto, H. 2018. Pengaruh mekanisme corporate governance, kualitas audit, ukuran perusahaan dan leverage terhadap integritas laporan keuangan. Jurnal Aplikasi Akuntansi, 2(1), 95-95.

[24] Boediono, G. S. 2005. Kualitas laba: Studi pengaruh mekanisme corporate governance dan dampak manajemen laba dengan menggunakan analisis jalur. Proceedings of the Simposium Nasional Akuntansi VIII, pp. 175-194.

[25] Gramling, A. A., Maletta, M. J., Schneider, A., \& Church, B. K. 2004 The role of the internal audit function in corporate governance: A synthesis of the extant internal auditing literature and directions for future research. Journal of Accounting Literature, 23, 194-244.

[26] Haron, H., Chambers, A., Ramsi, R., \& Ismail, I. 2004. The reliance of external auditors on internal auditors. Managerial Auditing Journal, 19(9), 1148-1159.

[27] Herawaty, S. A. 2007. Analisis pengaruh independence, mekanisme corporate governance, dan kualitas audit terhadap integritas laporan keuangan. Proceedings of the Simposium Nasional Akuntansi X.

[28] Ikatan Akuntan Indonesia (IAI). 2012. Standar Akuntansi Keuangan (SAK). IAI.

[29] International Accounting Standard Board (IASB). 2001.

[30] International Standard on Auditing (ISA) No. 1. 2017. Internasional Financial Reporting Standart (IFRS). 21(1).

[31] Jamaan. 2008. Pengaruh mekanisme corporate governance, dan kualitas kantor akuntan publik terhadap integritas informasi laporan keuangan. jurnal akuntansi dan keuangan. Universitas Diponegoro.

[32] James, K. L. 2003. The effects of internal audit structure on perceived financial statement fraud prevention. Accounting Horizons, 17(4), 315 327.

[33] Kieso, D. E., Jerry, J. W., \& Terry, D. W. 2011. Intermediate accounting. John Wiley and Sons.
[34] Klein, A. 2002. Audit committees, board of director characteristics and earnings management. Journal of Accounting and Economics, 33(3), $375-400$.

[35] Krishnan, G. V. 2003. Audit quality and the pricing of discretionary accruals. Auditing: A Journal of Practice and Theory, 22(1), 26-109.

[36] Krishnan, G. V. 2003. Does Big 6 auditor industry expertise constrain earnings management? Accounting Horizons, Supplement, 1-16.

[37] Krishnan, J. 2001. Corporate governance and internal control: An empirical analysis. American Accounting Association Annual Meeting.

[38] Krishnan, J. 2005. Audit committee quality and internal control: An empirical analysis. The Accounting Review, 80(2), 649-675.

[39] Lam, W. P., \& Arens, A. A. 1976. Audit committees in practice: A survey. C.A. Magazine, pp. 49-57.

[40] Levitt, A. 1999. Levitt plays up shareholder rights to directors. Investor Relations Business, 12(2).

[41] Levitt, A. 1998. Corporate governance: Integrity in the information age. Tulane University.

[42] Levitt, A. 1999. Remarks of chairman Arthur Levitt to the panel on audit effectiveness of the public oversight board. Public Oversight Hearings.

[43] Levitt, A. 2000. Remarks delivered at the Economic Club of Washington.

[44] Levitt, A. 2000. Renewing the covenant with investors. New York University Center for Law and Business.

[45] Goodwin, J., \& Seow, J. L. 2002. The influence of corporate governance mechanisms on the quality of financial reporting and auditing: Perceptions of auditors and directors in Singapore. Accounting and Finance, 42(3), 195-223.

[46] Lin, C. 2001. Private vices in public places: Challenges in corporate governance development in China. Discussion paper, Centre of Development, OCDE.

[47] Lowe, D. J., Geiger, M. A., \& Pany, K. 1999. The effects of internal audit outsourcing on perceived external auditor independence. Auditing: A Journal of Practice and Theory, 18(Supplement), 7-26.

[48] McConomy, B., \& Bujaki, M. 2000. Corporate governance. CMA Management, 74(8), 10-13.

[49] McMullen, D. A., \& Raghunandan, K. 1996. Enhancing audit committee effectiveness. Journal of Accountancy, 182(2), 79-81.

[50] McMullen, D. A. 1996. Audit committee performance: An investigation of the consequences associated with audit committees. Auditing: A Journal of Practice and Theory, 15(1), 87-103.

[51] Mulyadi. 2002. Auditing. PT. Salemba Empat Patria

[52] Piesse, J., Strange, R., \& Toonsi, F. 2012. Is there a distinctive MENA model of corporate governance. Journal of Management and Governance, 16(4), 645-681.

[53] Porter, B. A., \& Gendall, P. J. 1998. Audit committees in private and public sector corporates in New Zealand: An empirical investigation. International Journal of Auditing, 2(1), 49-69.

[54] Position Paper \#1 / 2003. Organisasi profesi internal auditor. Rekomendasi mengenai peran internal audit dalam meningkatkan corporate governance pada perusahaan di Indonesia.

[55] Sarbanes, P., \& Oxley, M. 2002. Sarbanes-Oxley Act of 2002. The Public Company Accounting Reform and Investor Protection Act.

[56] Securities and Exchange Commission (SEC). 2002. Disclosure Required by Section 404, 406 and 407 of the Sarbanes-Oxley Act of 2002. SEC.

[57] Shkolnikov. 2001. Corporate governance: Antidote to corruption. Transparency International.

[58] Steinberg, R. M., \& Pojunis, D. 2000. Corporate governance: The new frontier. The Internal Auditor.

[59] Swanger, S. L., \& Chewning, E. G. 2001. The effect of internal audit outsourcing on financial analysts' perceptions of external auditor independence. Auditing: A Journal of Practice and Theory, 20(2), 115129.

[60] Tanenhaus, M., Vinzi, E. V., Chatelin, Y. M., \& Lauro, C. 2005. PLS path modeling. Computational Statistics and Data Analysis, 48(1), 159-205.

[61] National Commission on Fraudulent Financial Reporting (US) 1987. Report of the National Commission on Fraudulent Financial Reporting. The Commission.

[62] Virginia, A., \& Eleni, K. 2008. The role of financial accounting information in strengthening corporate control mechanisms to alleviate corporate corruption. University of Macedonia.

[63] Ward, D. D., \& Robinson, J. C. 1980. Reliance on internal auditors. Journal of Accountancy, pp. 62-73.

[64] Wright, A., G. Krishnamoorthy, and J. Cohen. 2004. The impact of corporate board focus on auditors' program planning judgments. Working paper, Boston College.

[65] Wulandari, R. E. 2011. Good corporate governance. LKDI. 